\title{
PHYSICO-CHEMICAL AND MECHANICAL PROPRIETIES OF SUPERSULPHATED CEMENT PASTES
}

\author{
El-Didamony, $\mathbf{H}^{\mathrm{a}}$.; Amer A.A ${ }^{\mathrm{a}}$; E., Ewais E.M ${ }^{\mathrm{b}}$; Shokry, $\mathrm{K}^{\mathrm{a}}$ \\ ${ }^{a}$ Chemistry Dept., Faculty of Sci., Zagazig Univ., Zagazig, Egypt. \\ b Refractory and Ceramic Materials Division Central Metallurgical R \& D Institute \\ * Corresponding author \\ Dr. Ahmed A Amer drahmed.amer@zu.edu.eg Tel. +201210088668
}

\begin{abstract}
Phosphogypsum (PG) is a naturally occurring part of the process of creating phosphoric acid. The raw phosphate is treated by sulphuric acid, deside the main product phosphoric acid, phoso-gypsum and small quantity of hydrofluoric acid are obtained. The aim of this work is to study the possibility of using granulated blast furnace slag (GBFS), PG and (OPC) for preparation of supersulphated cement (SSC). The hydration, strength development of the hydration products of SSC are characterized in hydrated pastes cured in tap water up to 90 days. Some selected samples are examined by XRD and DTA techniques to show the main hydration product.
\end{abstract}

Keywards: Supersulphated Cement, hydration, phosphogypsum, granulated blast furnace slag, strength, DTA, XRD.

\section{INTRODUCTION}

Phosphogypsum (PG) consists primarily of calcium sulphate diydrate with small amounts of silica, usually as quartz and unreacted phosphate rock.Radium and uranium, as well as minor amounts of toxic metals are also present in PG. There are several areas of utilization for PG. The two main fields are conversion of PG to plaster products and replacement of natural gypsum in cement production. Unfortunately, high energy consumption is needed to dry PG and the utilization of phosphogypsum is therefore limited (Kuryatnyk et al. 2008]. The use of PG in cements has received much attention, because it is obtained in large amounts and is a readily available source of gypsum to regulate the setting of OPC. It was shown that the impurities present in PG retarded the hydration of OPC to large extent. In 
order to overcome this problem, a rafination method of PG was used in OPC without undue retardation (Erdem and Ölmez, 1993].

SSC consists mainly of GBFS mixed with 10 to 15 wt \%, hard-burned gypsum (natural anhydrous calcium sulphate) and a few percent of (OPC). The strength is similar to that of PC, but it has an increased resistance to many forms of chemical attack (Mehrotra et al. 1982].

GBFS is the non-metallic by-product of pig iron production, when rapidly cooled forms a highly reactive glassy material with latent cementitious characteristics (Bazaldúa-Medllin et al. 2015]. The potential of the GBFS as a cementitious material depends on its reactivity, which is greatly influenced by the surface area, vitreous fraction and chemical composition. In order to exploit the cementitious nature of the GBFS, an activation process is necessary. Mechanical activation is attained by increasing its surface area. On the other hand, chemical activation is possible by means of several reagents, such as alkalis, sulphates, OPC, etc., resulting in cement of strength and durability sometimes higher than those of OPC (Hewlett, 2004]. This makes the GBFS an excellent alternative cementitious material for mortar and concrete applications.

The activation of GBFS by sulphates was described (Gruskovnjak et al. 2008). Generally, the chemical activation routes for the GBFS, that with sulphates has been successfully used for years in what is known as (SSC). These green cements are regaining attention and are thought to have promising potential for different applications (Gartner, 2004). The main hydration products are reported as AFt and (C-S-H) (Gruskovnjak et al. 2008; Fernández Jiménez et al. 1996 \& Ko, 2002)

There are not many reports of SSC using various compositions. Midgley and Pettifer (1971) reported on pastes with 88\% GBFS, 10\% gypsum and 2\% OPC, described microstructures formed by the formation of long laths of abundant AFt ith plate like C-S-H. Bijen and Niël (1981) reported on mortars and concretes cured for up to 56 days, using SSC and made with several GBFS at $79-83 \%$, 2-7\% clinker and $14-15 \%$ of $\mathrm{CaSO}_{4}$ (PG or FG). They found that PG retarded the setting compared to FG. The concretes showed a behavior similar to that of mortars.

Erdem and Ölmes (1993) investigated cementitious pastes of GBFS (80$85 \%)$, PG (10-18\%) and PC clinker (2-5\%), with a w/s ratio of 0.25 ; cured in tap water and synthetic seawater up to 90 days. They found that, the highest compressive and flexural strengths were for the mix 85\% GBFS, 10\% PG and $5 \%$ clinker. In contrast with Bijen and Niël (1981) they reported that a reduction in clinker content resulted in a drastic drop in strength.

O'Rourke et al. (2009) reported mortars of slag contents lower than SC, of 66-70\% GBFS, 3.4\% $\mathrm{CaSO}_{4}$, and relatively high contents of OPC 27-30\%; at water/solid ratio of 0.5 and cured at $20{ }^{\circ} \mathrm{C}$ under water. All formulations 
showed very close strength development reaching about $42 \mathrm{MPa}$ at 90 days. Kondo et al. (1980) studied formulations of $90 \%$ GBFS and $10 \%$ anhydrite with additions of up to $2 \% \mathrm{Ca}(\mathrm{OH})_{2}$ and reported on the evolution of the reactions in pastes with a water/solids ratio of 0.4 for 28 days. It was concluded that $0.3 \% \mathrm{Ca}(\mathrm{OH})_{2}$ was optimum, and that ettringite and $\mathrm{C}-\mathrm{S}-\mathrm{H}$ were the main hydration products. In this work the hydration characteristics of SSC prepared with replacement of GBFS with PG in presence of $5 \mathrm{wt} \%$ of OPC are evaluated.

\section{MATERIALS AND METHODS}

The materials used in this study were (GGBS), (PG) and (OPC). The GBFS is provided from iron and steel, Co. Helwan. The (PG) is provided from (Abo Zaabal Fertilizer \& Chemical Co, Egypt). The OPC is obtained from Suez Cement Company, Suez plant. The chemical compositions of the starting materials are given in Table (1). The mineralogical composition of GBFS was seen from XRD pattern in Fig. (1). It shows that GBFS is nearly vitreous with an amorphous structure indicated by a broad diffuse hump peak in the region of $2 \theta\left(20-35^{\circ}\right)$ (Abd El-Aziz, 2010). GBFS particle morphologies are examined using (SEM) and presented in Fig. (2). GBFS is mainly composed of pyramid like particles with an average size of $7 \mu \mathrm{m}$. The micrograph also shows some irregular shape particles with a dense-compact structure with an average size of $20 \mu \mathrm{m}$. The Blaine surface area was $3000 \pm 50 \mathrm{~cm}^{2} / \mathrm{g}$. The mineralogical composition of PG was seen from XRD Pattern in Figure (3). It shows the presence of hemihydrate and anhydrite as main minerals with small amount of quartz $\left(\mathrm{SiO}_{2}\right)$.

\subsection{Mixing of Cement Paste}

An amount of cement is placed on a smooth, non-absorbent surface, and a crater is formed in the center. The determined amount of water of consistency is poured into the crater by the aid of a trowel. Continuous and vigorous mixing was made for three min. by means of gauging trowel then completed the mixing operation. The paste is placed in $2 \times 2 \times 2 \mathrm{~cm}$ cubic moulds, pressed into the corners and along the surface of the mould until homogeneous specimen was obtained. The surface of the paste is smoothed by the aid of edged trowel. Immediately after molding, specimens are cured at (100\% R.H.) at room temperature $23 \pm 2{ }^{\circ} \mathrm{C}$ for $24 \mathrm{hrs}$. At the end of the moist curing period, the cubes are demoulded and cured in tap water up to 90 days. 
Table (1): Chemical composition of starting materials, wt $\%$

\begin{tabular}{|c|c|c|c|}
\hline \multirow[t]{2}{*}{ Oxides } & \multicolumn{3}{|c|}{ Starting Materials } \\
\hline & GBFS & PG & OPC \\
\hline $\mathrm{CaO}$ & 41.66 & 31.48 & 62.72 \\
\hline $\mathrm{SiO}_{2}$ & 34.20 & 6.03 & 20.68 \\
\hline $\mathbf{A l}_{2} \mathbf{O}_{3}$ & 10.06 & 0.48 & 4.90 \\
\hline $\mathrm{Fe}_{2} \mathrm{O}_{3}$ & 1.58 & 0.50 & 3.35 \\
\hline MgO & 7.14 & 0.18 & 2.64 \\
\hline $\mathrm{SO}_{3}$ & 2.21 & 40.42 & 2.65 \\
\hline $\mathrm{K}_{2} \mathrm{O}$ & 0.48 & 0.11 & 0.11 \\
\hline $\mathrm{Na}_{2} \mathrm{O}$ & 0.34 & 0.03 & 0.14 \\
\hline $\mathbf{P}_{2} \mathbf{O}_{5}$ & 0.02 & 1.27 & 0.10 \\
\hline $\mathrm{Mn}_{2} \mathrm{O}_{3}$ & 1.12 & 0.00 & 0.00 \\
\hline L.O.I & 0.03 & 19.10 & 2.73 \\
\hline Total & 98.86 & 99.60 & 98.14 \\
\hline
\end{tabular}

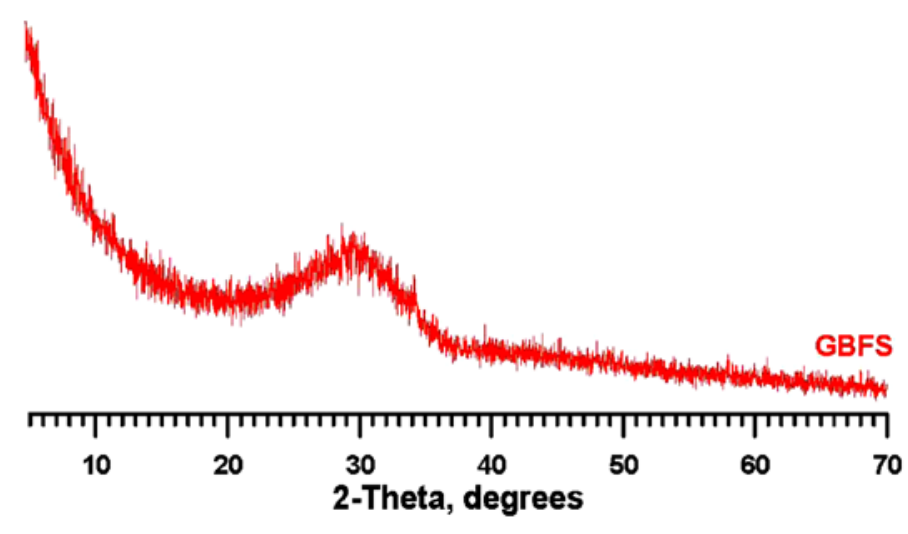

Fig. (1) XRD pattern of granulated blast furnace slag (GBFS)

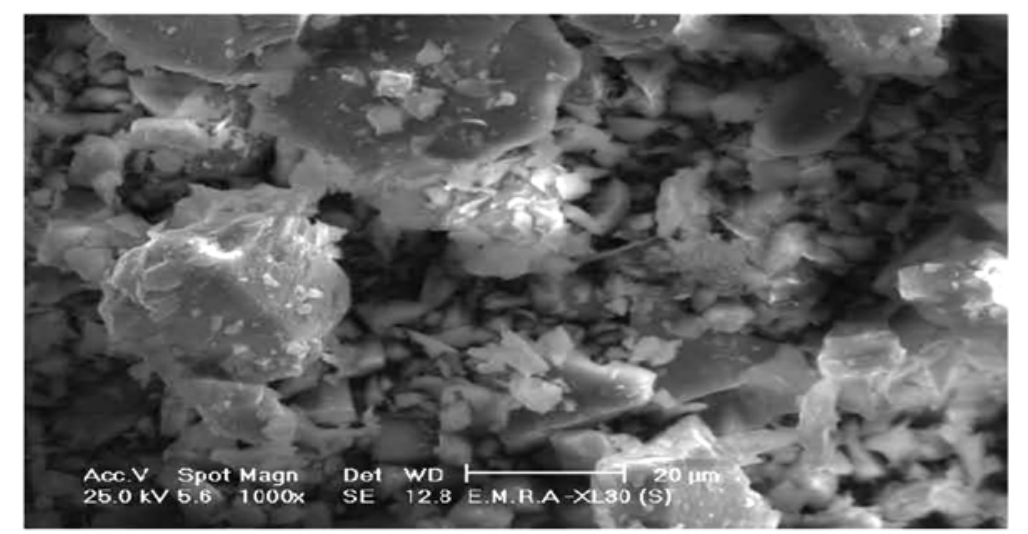

Fig. (2) SEM of granulated blast furnace slag (GBFS) 


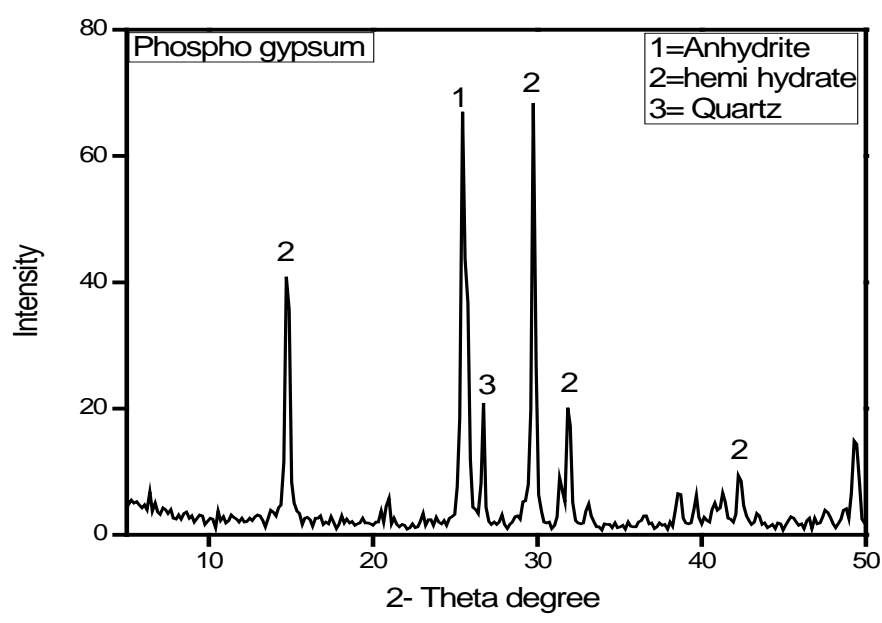

Fig. (3) XRD pattern of phosphogypsum (PG)

\section{2- Preparation of Starting Materials}

The GGBFS is crushed by Jaw crusher and finely ground by using a laboratory small steel ball mill having a capacity of five kilograms. It passed through 90 micron B.S. Sieve and residue on sieve was $6 \%$ then sieved through 45 micron retaining residue of $30 \%$ on sieve.

Phosphogypsum is burnt in muffle furnace at $750^{\circ} \mathrm{C}$ for two hours, crushed by Jaw crusher and finely ground using a laboratory steel ball mill having a capacity of five kilograms. It passed through 90 micron B.S. Sieve and residue on sieve was $6 \%$ then sieved through 45 micron retaining residue of $18 \%$ on sieve.The ingredients of each mix homogenized in a ball mill using 3 balls for 30 minutes to attain complete homogeneity are as shown in Table (2).

Table (2): Mix composition of the investigated mixes, wt\%

\begin{tabular}{|c|c|c|c|}
\hline Sample No & GGBFS & PG & OPC \\
\hline M1 & 75 & 20 & 5 \\
\hline M2 & 80 & 15 & 5 \\
\hline M3 & 85 & 10 & 5 \\
\hline M4 & 90 & 5 & 5 \\
\hline
\end{tabular}

\subsection{Methods of Investigation}

The standard water of consistency as well as initial and final setting times are determined according to (BS EN 196-3, 1995) using Vicat apparatus. The hydration of these pastes is stopped using an acetone-methanol mixture (ElDidamony et al., 19960. The rate of hydration is followed by the determination of chemically combined water (Soroka, 1986). Free $\mathrm{SO}_{3}$ in the 
hardened cement pastes is determined by the method suggested by Forsen (Amer, 1990). The bulk density is carried out before the pastes subjected to compressive strength determination (Tkalcec and Zellic, 1987). The compressive strength was determined as described elsewhere (Regourd et al. 1983). The hydration products of some selected pastes are characterized for the samples finely ground to pass a 200-mesh sieve. using XRD, DTA and TGA techniques.

\section{RESULTS AND DISCUSSION}

\section{1- Water of Consistency and Setting times}

The standard water of consistency, initial and finalsetting tims of SSC pastes are graphically represented as a function of anhydrite PG in Fig. (4). It is observed that PG provides additional stiffness to the paste and thereby, the standard water of consistency increases with PG contents and both setting times elongate. This is due to the reaction of PG with GBFS particles forming AFt or AFm, these phases needed more water than C-S-H (Bhadauria and Thakare, 2006).

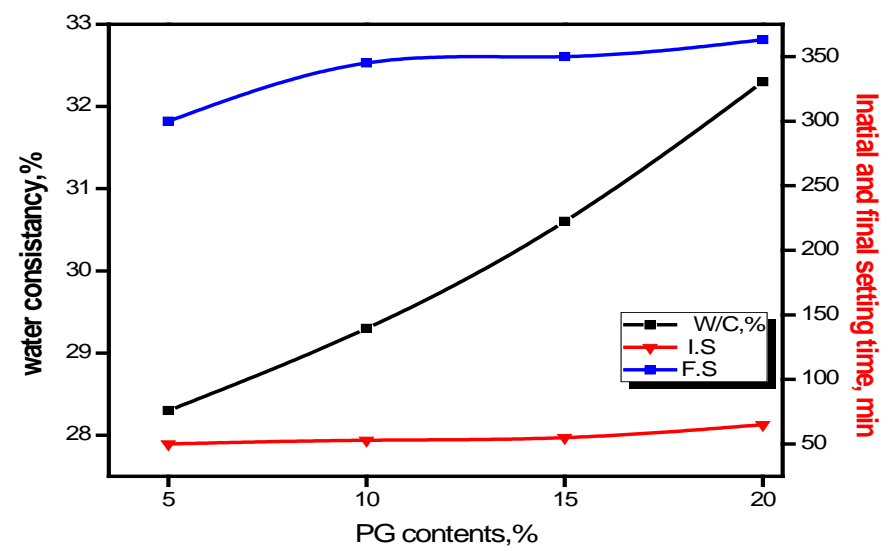

Fig. (4) Water of consistency, initial and final setting time of SSC pastes

\section{2- Chemically Combined Water Content}

The chemically combined water contents (Wn) of hydrated SSC pastes cured up to 90 days are graphically plotted in Fig. (5). It is clear that Wn\% increases gradually with curing time for all cement pastes. This is due to the continuous hydration of GBFS with PG in presence of OPC and accumulation of hydration products as $\mathrm{C}-\mathrm{S}-\mathrm{H}$ and (AFt and/or AFm). The Wn, \% content increases with PG up to $15 \%$ and then decreases with 5 and $10 \%$ PG. This is mainly due to the increase of the mixing water in addition to the formation of Aft and C-S-H. It can be said that $15 \mathrm{wt} \%$ of PG is the optimum amount in this mix. $\mathrm{CaSO}_{4}$ acts as a sulphate activator which accelerates the reaction of slag glasses. The reaction between GBFS and calcium sulphate is utilized to a much greater extent in SSC (Kondo et al. 1980). It can be also that, the decrease of combined water content with lower amount of (5-10\%) PG is 
mainly due to the decrease of ettringite which has high water content. On the other hand, M3 gives the lower values than all mixes due to the presence of 85\% GBFS and 10\% PG which delay the rate of hydration.

\section{3- Thermal analysis of SSC pastes}

Fig. (6) illustrates the DTA thermograms of SSC pastes after 90 days. All cement pastes show the appearance of an endothermic peak at lower temperatures $\left(100-300^{\circ} \mathrm{C}\right)$, due to the decomposition of small amounts of AFt, gypsum and C-S-H (Amer, 1998).

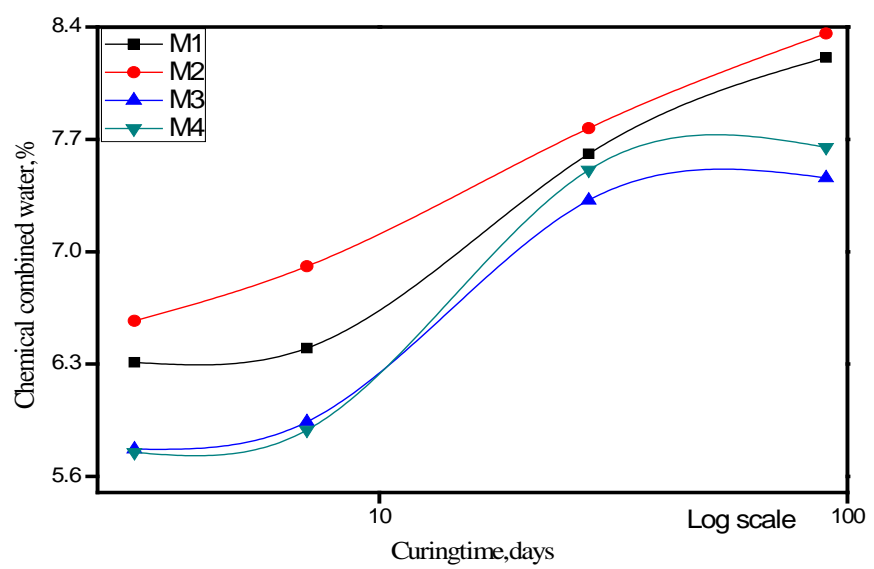

Fig. (5) Chemically combined water contents for SSC pastes up to 90 days

The intensity of the endothermic peaks increases with PG content. This is mainly attributed to the higher hydration products and residual PG. The patterns show no endothermic peaks in the range of the decomposition of portlandite due to its absence. The DTA thermograms show small endothermic peaks at $750-900^{\circ} \mathrm{C}$ which is due to the decomposition of $\mathrm{CaCO}_{3}$. One of the most important issues of (SSCs) is carbonation, and especially when curing is insufficient which causes a decomposition of the AFt and increases in capillary porosity and pulverization of the concrete skin (Garrault et al.,2005). To prevent skin formation the penetration of ambient air during early hydration (Thomas et al.,2009). 


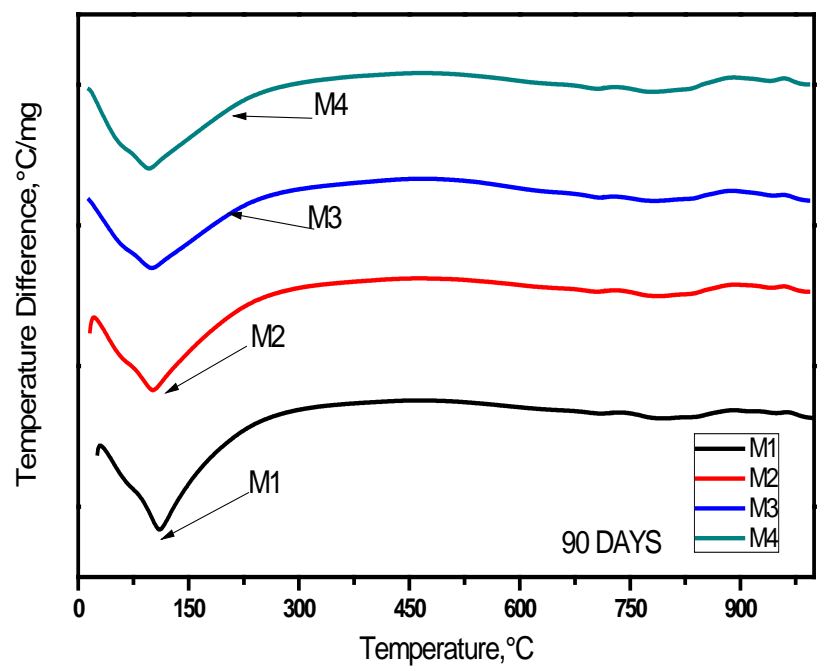

Fig. (6) DTA thermograms of the hydrated SSC pastes with

Fig. (7) illustrates the TG thermograms of SSC pastes up to $1000^{\circ} \mathrm{C}$. The results of TG are in agreement with those of DTA. Mix M1 gives the higher TG of SSC pastes. The TG of all cement pastes from room temperature up to $300^{\circ} \mathrm{C}$ is due to the decomposition of hydration products at lower temperature as shown on the DTA thermograms. As the temperature increases up to $550^{\circ}$ $\mathrm{C}$, there is slight TG which is due to the carbonationof $\mathrm{C}-\mathrm{S}-\mathrm{H}$ which is carbonated C-S-H. Also, as the temperature increases from $700-1000^{\circ} \mathrm{C}$ the TG increase due to the decomposition of $\mathrm{CaCO}_{3}$. The low content of OPC has $\mathrm{pH}$ value which can activate the GBFS hydration. As the OPC content increases the residual portlandite retards the hydration and then the TG of $\mathrm{CO}_{2}$ increase.

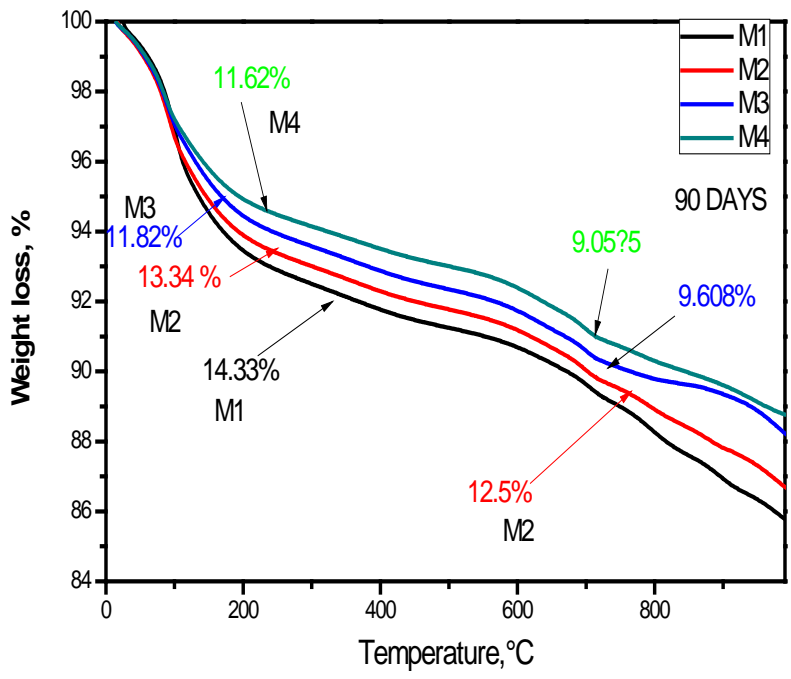

Fig. (7) TGA thermograms of the hydrated SSC pastes cured at 90 days 


\section{4- XRD Analysis:}

Fig. (8) shows the XRD patterns of SSC pastes hydrated for 28 days. M1 shows the presence of PG anhydrite and decreases in M3 and M4 pastes. This is mainly due to the decrease of PG in SSC pastes. The patterns illustrated the absence of ettringite or monosulphate hydrate or poorly formed. The GBFS is vitreous and glassy structure with the appearance of CSH and PG gypsum. The absence of AFt may be due that it is a nano-phase. The CSH is over lapped with the formed $\mathrm{CaCO}_{3}$. The PG is completely consumed after 28 days of hydration in mix (90, 5 and $5 \mathrm{wt} \%$ ) GBFS, PG and OPC respectively. The peaks of anhydrite decrease also with the decrease of PG in the original mix. The gypsum peak is also present in all mixes due to the gypsification of PG.

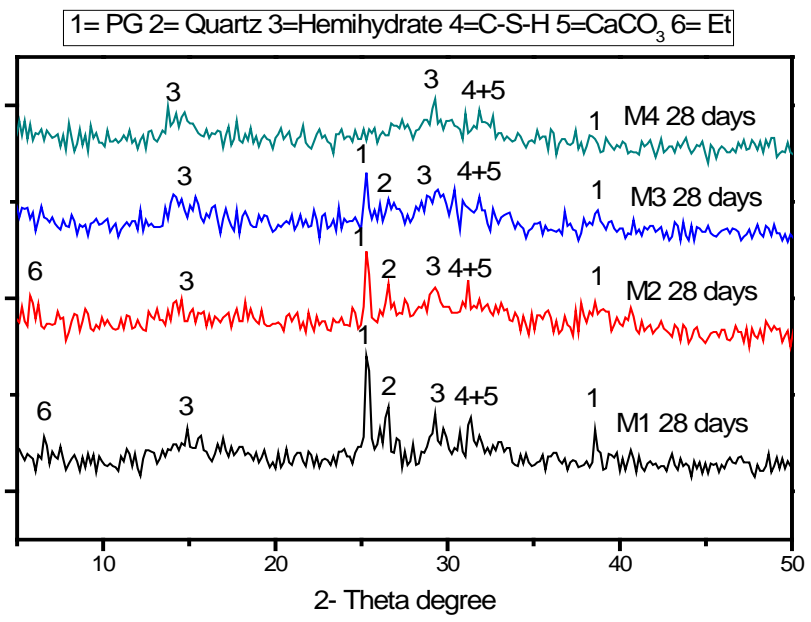

Fig. (8) XRD-Patterns of SSC paste with 5\% OPC at 28 days

\section{5- Free sulphate $\mathrm{SO}_{3}$ content}

The free $\mathrm{SO}_{3}$ contents of SSC pastes are plotted up to 90 days in Fig. (9). The free sulphate contents decrease with curing time up to 90 days for all cement pastes. The figure shows that the free $\mathrm{SO}_{3}$ increases with PG content and decreases with slag (GBFS) content. The dense cement paste structure of SSC is formed by ettringite and C-S-H, surrounded unreacted PG. This is due to the increase of PG as activator for GBFS. The presence of free $\mathrm{SO}_{3}$ in all cement pastes may be due to the decrease of the surface area of GBFS which is inactive to react with water and $\mathrm{CH}$ as well as $\mathrm{CaSO}_{4}$. The SSC pastes must need surface area not lower than $4000 \mathrm{~cm}^{2} / \mathrm{g}$. Also, the presence of free $\mathrm{SO}_{3}$ may be due to the adsorption of PG on the grains of GBFS.

\section{6-Bulk density}

The bulk density of the SSC pastes is plotted as a function of curing time up to 90 days Fig. (10). The bulk density increases with curing time for all SSC pastes due to the progress of hydration which gives more hydrated products and fill some of pores of cement pastes. As the hydration proceeds, more hydrated products are formed and precipitated within the pores originally 
water filled-spaces of the capillary pores. Therefore, the bulk density of SSC pastes increases with the progressive of hydration. Capillary porosity of SSC is very lower than that of OPC which is favorable with respect to durability. Sulfate resistance of SSC is quite satisfactory as compared to OPC. The increase of bulk density of SSC pastes is mainly due to the precipitation of AFt in the open pores which decreases the porosity. This increase is not only due to the hydration products AFt but also due to the increase of bulk density of unhydrated GBFS.

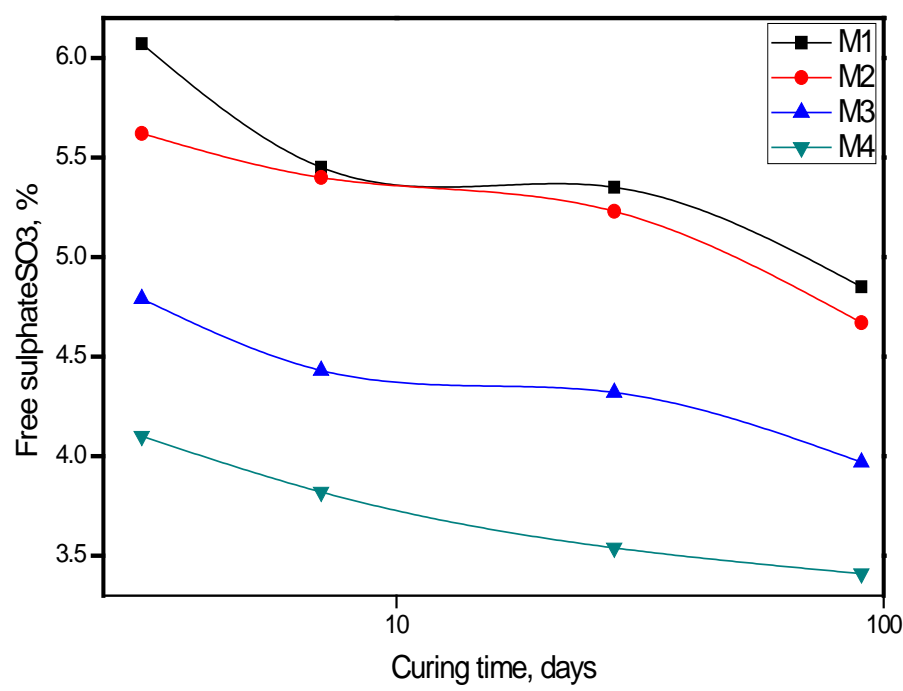

Fig. (9) Free sulphate $\mathrm{SO}_{3}$ of SSC pastes with 5\% OPC up 90 days

On the other hand, it is shown that the bulk density increases with GBFS content and with decreasing PG content as shown in M4 (90/5) which due to lower specific gravity of PG and increase the water of consistency with PG. This is also due to formation more ettringite which has low density than $\mathrm{CSH}$. Mix M4 considers the highest bulk density. This is due to the continuous accumulation of hydration products as C-S-H and AFt in some of the open pores.

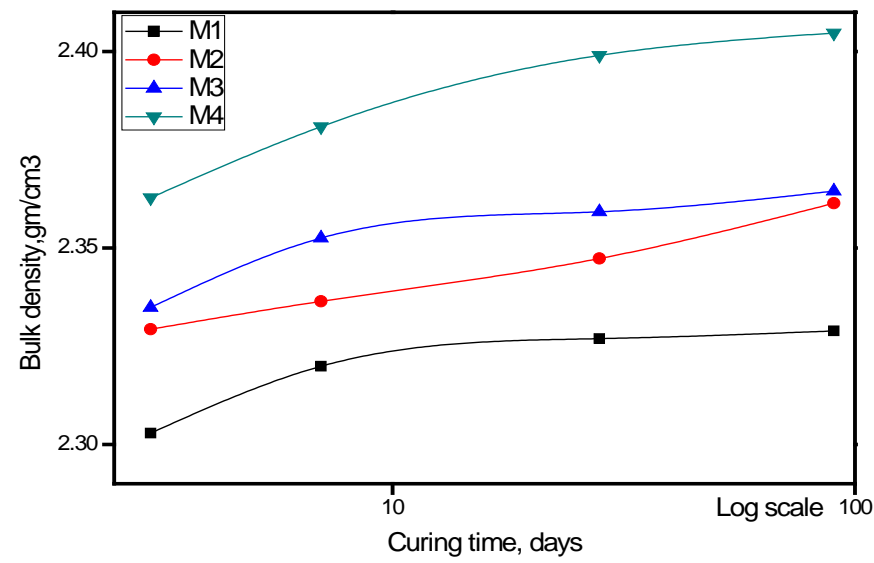

Fig. (10) bulk density of SSC pastes with5\%OPC up to 90 days 


\section{7- Compressive strength}

The compressive strength of the SSC pastes up to 90 days are represented in Fig. (11). The figure shows that the compressive strength increases with curing time for all cement pastes. This is mainly due to the increase of hydration products especially C-S-H which is the main source of Fig. (11) Compressive strength of SSC pastes with 5\% OPC up to 90 days the strength. Actually, these hydration products possess larger specific volume than that of the unhydrated cement; hence the accumulation of hydration products fill a part of the available pores.

As a result, the total porosity decreases and compressive strength increases. It is seen that the hardened paste of mix M4 (90/5) (slag/anhydrite) exhibits the highest compressive strength at all curing times compared with the other cement pastes. This is attributed to the development of the microstructure of cement pastes. The initial strength of SSC is due to the formation of ettringite whereas the formation of $\mathrm{CSH}$ is responsible for the strength development of cement pastes at later ages of hydration due to the pozzolanic reaction (Erdems and olmez, 1993). The compressive strength at 7, 28 and 90 days decreases with the gypsum content of slag rich cement. In contrast the strength was favored by higher PG and lower OPC contents. These cements generated heats of hydration of which are lower than OPC (BazaldúaMedellínetal.2015). From Figure () it is clear that the compressive strength increases with GBFS contents and with decreasing PG. (Erdems and Ölmez,1993).

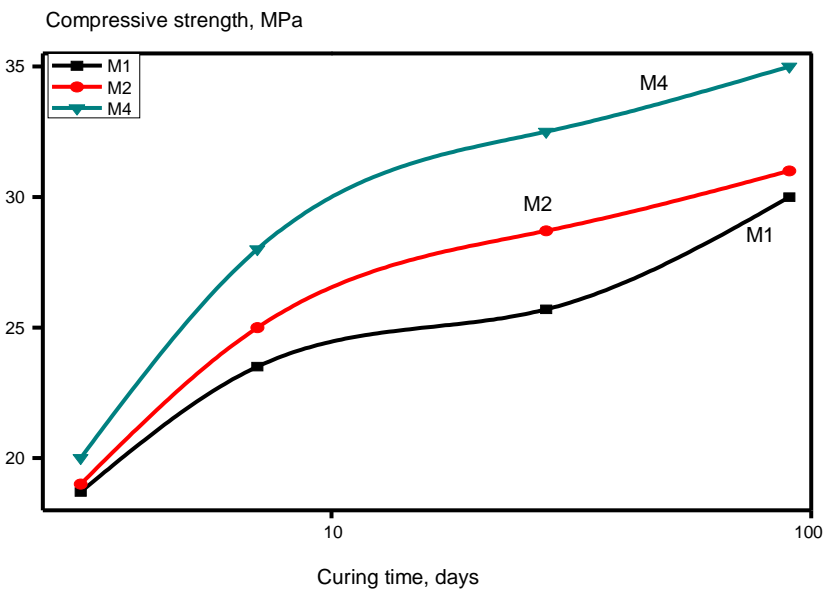

Fig. (11) compressive strength of SSC pastes with5\%OPC up to 90 days

On the other hand, mix M1 (75/ 20) (slag/anhydrite) gives the lowest compressive strength up 90 days. This may be attributed to the unreacted 
$\mathrm{CaSO}_{4}$ in the hardened paste which is more necessary than to the formation of hydrated AFt (ettringite). Increasing the amount of PG content decreases the strength of SSC at later ages (90 days) (Ali, 2013). This is due to the increase of free PG and to the nature of the hydrated phases such as etrringite which has low strength than CSH. Also, it is shown that the impurities present in PG retarded the hydration of OPC to large extent (Erdems and olmez, 1993). The compressive strength of $>70 \%$ slag cement mortar, decreases with gypsum content (Matsushita,1990). The rate of hydration was rapid in the first 3 days, but subsequently depressed with time due to the formation of dense layer of hydration products on the unhydrated slag grains due to the formation of dense C-S-H. This may be due to the increase of PG on the expense of GBFS which forms more sulphoaluminate hydrate such as AFt with lower strength. The development of strength increases at later ages than earlt ages due to the more hydration of GBFS, giving C-S-H the main factor of strength.

\section{REFERENCES}

Abd El- Aziz, H., "Physico- Chemical Studies of Alkali - Activated Slag Pastes" M.SC., Fac. Sci., Zagazig university (2010).

Amer, AA, Utilization of the cement dust kiln in the manufacture of Blended cement, ph.D Thesis, fac of Sci . Zag. Univ. 1990.

Bazaldúa-Medellína, M.E., A.F. Fuentesa, A. Gorokhovskyb, J.I. EscalanteGarcía, Early and late hydration of supersulphated cements of blast furnace slag with fluorgypsum, Materiales de Construcción Vol. 65, Issue 2015, 0465-2746

Bijen, J., and Neil, E., " Supersulphated Cement from blast furnace slag and chemical gypsum available in the netth-erlands and neighbouring countries"Cem. Concr. Res. 11 (1981) pp. 307-22

BS EN 196-3: (1995), Method of testing cement: Determination of setting times and soundness

Bhadauria, S. B. Thakare, Utilization of Phosphogypsum in cement mortar and concrete, 31st Conference on Our World in concrete \& Structure, (2006) Singapore

El-Didamony, H., Amer, A.A., Helmy, I.M., and Mostafa, K., "Durability of Sulphate Resisting Slag Blended Cement and Mortar in Seawater" Indian J. Eng. Mater. Sci., 3, (1996) pp. 35- 40.

E. Erdem and H. Olmez, The mechanical properties of super sulphated cement containing phosphogypsum, Cem. Concr. Res. 23(1), (1993) 115-121

Fernández Jiménez, A.; Puertas, F.; Fernández Carrasco, L. Alkalinesulphate activation processes of a spanish blast furnace slag. Mater. Construcc. 46 (1996), 23-37 
Gruskovnjak, A.; Lothenbach, B.; Winnefeld, F.; Figi, R.; Ko, S.C.; Adler, M.; Mäder, U Hydration mechanisms of super sulphated slag cement. Cem Concr Res. 38 (2008) 983-992.

Gartner, E. Industrially interesting approaches to "low-CO2" cements. Cem Concr Res. 34, (2004) 1489-98.

Garrault.S. Finot., E., Lesniewska, E., Nonat.A., study hydrationmaterials\& structure 38 (2005) $435-442$

Hewlett PC, Lea's Chemistry of cement and concrete, Elsevier ButterworthHeinmann, (2004).

Kondo, R.; Daimon, M.; Song, C.; Jinawath, S. Effect of lime on the hydration of super-sulfated slag cement. American Ceramic Society Bulletin. (1980) 848-851.

Ko, S.C. Alkali activated supersulphated blinder. United States Patent. Patent $\mathrm{N}^{\circ}$ : US 6,409,819 B1 (2002)

Kuryatnyk, T., C. Angulski da Luz, Ambroise,J. pera,, Valorization of Phosphogypsum as hydraulic binder.Journal of hazardous materials (160) (2008), 681-687

Matsushita, H., Semento Konkurito Robounshu, 144, P. 174 Japan (1990).

Midgley, H.G.; Pettifer, K, The micro structure of hydrated super sulphated cement. Cem. Concr Res. 1, (1971) 101-104

Mehrotra, V.P.; Sai, A.S.R.; Kapur, P.C Plaster of Paris Activated Supersulphated Slag Cement. Cem Concr Res. 12, (1982), 463-473

O’Rourke, B.; McNally, C.; Richardson, M.G,,Development of calcium sulfate-ggbs-Portland cement binders. Constr and Build Mat. 23, (2009) 340-346.

Regourd M, Thomassin JH, Baillid P, Touray JC. Bast furnace slag hydration. Surface analysis, Cem. concr Res. 1983, 13 (4) :549-556.

Soroka I. Portland cement paste and concrete. The Macillan press LTD., (1986)

Thomas J.J, Allen A.J, Jennings H.M., Hydration kinetics and microstructure development of normaland $\mathrm{CaCl}$-accelerated tricalcium silicate (C3S) pastes, J. Phys. Chem. C 113 ,19836-19844, (2009).

Tkalcec E. and Zellic J. Influence of amorphous silica (silica dust) on the proprieties of Portland cement mortars. Zement- Kalk- Gips 1987, 11:71073 
الخواص الفيزيقو- كيميائية والميكانيكية لعجائن الأسمنت الفوق مقاوم للكبريتات

حمدي الديداموني' ، أحمد عبد المنعم عامر'، عماد محمد عويس 'وكرم شكري'

$$
\begin{aligned}
& \text { ا قسم الكيمياء، كلية العلوم جامعة الزقازيق } \\
& \text { r مركز بحوث وتطوير كلية الفلزم جامعة قسم الموازيق السير اميكية و الحر ارية }
\end{aligned}
$$

من نواتج تحضير حمض الفوسفوريك من خام فوسفات الكالسيوم نفايه صناعيه تسمى الفوسفو

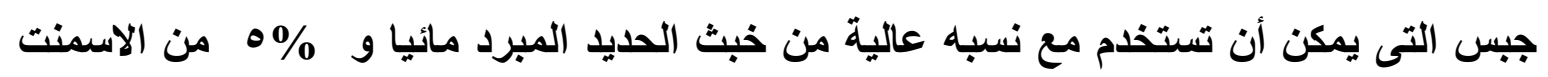
البورتلاندى لتحضير اسمنت عالى الكبريتات. يعتبر هذا الاسمنت من الاسمنتات التى تعمل على توفير الطاقه ونظافه البيئه. امكن تحضير اسمنت عالى الكبريتات من المواد السابقه ( خبث الحديد والفوسفو جبس والاسمنت البورتلاندى ) وينسبه لونه

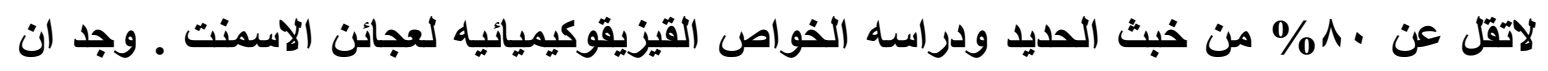

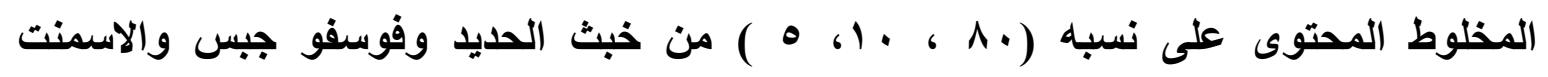
البورتلاندى العادى على التوالى اعطى نتايج جيده من قوى التحمل وكيناتيكيه التادرت حتى ثنلاثه شهور. لقد تطابقت نتائج التأدرث مع الخواص الفئل الفيزيقو - ميكانيكيه. 